UNIVERSITAS MUHAMMADIYAH MATARAM
JURNAL ELEMENTARY
http://journal.ummat.ac.id/index.php/elementary
$2614-5596$ (Online)

\title{
Identifikasi kesamaan jenis praktikum pada materi IPA di tingkat SD dan SMP
}

\section{Yuanita}

STKIP Muhammadiyah Bangka Belitung

Yuanitaa87@gmail.com

\begin{tabular}{ll}
\hline Informasi artikel & ABSTRAK \\
\hline Sejarah artikel: & Praktikum IPA diberikan pada tingkat SD, SMP, SMA bahkan sampai tingkat \\
Diterima: 3I Mei 20I8 & perguruan tinggi. Akan tetapi dalam pelaksanaanya terkadang ada beberapa \\
Revisi: 05 Juni 20I8 & kesamaan pada jenis praktikum atau pengulangan jenis praktikum yang diberikan \\
Dipublikasikan: 30 Juni 20I8 & untuk menunjang kedalaman terhadap materi yang dipelajari. Hal ini terkadang \\
\hline Kata kunci: & dapat menyebabkan kejenuhan siswa dan kurang membangkitkan keingintahuan \\
Kesamaan Jenis Praktikum & siswa karena mereka sudah tahu hasil akhirnya. Penelitian ini merupakan kajian \\
Materi IPA & literatur pada beberapa buku IPA tingkat SD dan SMP yang bertujuan \\
& mengindentifikasi beberapa kesamaan jenis praktikum yang terdapat pada materi \\
& IPA pada tingkat SD dan SMP. Berdasarkan hasil kajian literature tersebut peneliti \\
& menemukan 6 (enam) kesamaan praktikum pada tingkat SD dan SMP; I) Listrik \\
& dan Magnet, 2) Perubahan Wujud Benda, 3) Perubahan Pada Makhluk hidup, 4) \\
& Sistem gerak pada tumbuhan, 5) Struktur bagian bunga, dan 6) Konduktor dan \\
& isolator.
\end{tabular}

\section{Pendahuluan}

Praktikum menjadi bagian yang integral dalam pendidikan Ilmu Pengetahuan Alam (IPA) baik ilmu fisika, kimia maupun Biologi. Hal ini menunjukkan bahwa betapa pentingnya peranan praktikum dalam pencapaian tujuan-tujuan pendidikan IPA. Sedikitnya ada empat alasan yang dikemukan para pakar pendidikan mengenai pentingnya kegiatan praktikum (Woolnough \& Allsop dalam Rustaman (I995: 5-8) pertama, praktikum membangkitkan motivasi belajar IPA. Kedua, praktikum mengembangkan motivasi belajar IPA. Ketiga, praktikum mengembangkan keterampilan-keterampilan dasar melaksanakan eksprimen. Keempat, praktikum menjadi wahana belajar pendekatan ilmiah.

Berdasarkan terminologinya, praktikum dapat diartikan sebagai suatu rangkaian kegiatan yang memungkinkan seseorang (siswa) menerapkan keterampilan atau mempraktikkan sesuatu. Dalam pembelajaran IPA, sesuatu ini adalah proses-proses sains sebagaimana yang diuraikan dalam tabel I di atas. Dengan kata lain, di dalam kegiatan praktikum sangat dimungkinkan adanya penerapan beragam keterampilan proses sains sekaligus pengembangan sikap ilmiah yang mendukung proses perolehan pengetahuan (produk keilmuan) dalam diri siswa. Di sinilah tampak betapa praktikum memiliki kedudukan yang amat penting dalam pembelajaran IPA (Subiantoro, 2007:7).

Keberadaan praktikum banyak didukung oleh para pakar psikologi belajar, pakar IPA maupun para pakar pendidikan, sekalipun masing- masing meninjau dari sisi yang berbeda tentang manfaat praktikum. Selain itu hasil-hasil riset yang dilaporkan dalam jurnal profesional di bidang pendidikan IPA serta abstrak disertasi atau skripsi menunjukkan efek positif dari praktikum terhadap pengajaran IPA. Walaupun secara formal praktikum sudah menjadi komponen dalam pembelajaran di sekolah-sekolah di Indonesia, namun dalam hal ini bisa dibahas lebih jauh apakah praktikum di sekolah telah dilaksanakan optimal ataukah belum dalam rangka mencapai tujuan pembelajaran yang disuratkan kurikulum (Ahafni, 2013:I).

Praktikum IPA diberikan pada tingkat SD, SMP, SMA bahkan sampai perguruan tinggi. Akan tetapi dalam pelaksanaanya terkadang ada beberapa kesamaan pada jenis praktikum yang diberikan 
sehingga menyebabkan kejenuhan siswa maupun mahasiswa yang pernah mendapatkan materi tersebut. Oleh karena itu peneliti ingin menganalisis berapa persentase kesamaan jenis praktikum IPA yang terdapat pada beberapa buku IPA di tingkat SD dan SMP.

\section{Metode}

Penelitian ini termasuk jenis penelitian studi literatur dengan mencari referensi teori yang relevan dengan kasus atau permasalahan yang ditemukan. Referensi teori pada penilitian ini mengunakan data sekunder yang diperoleh dari beberapa buku.

\section{Hasil dan pembahasan}

Kata praktikum berasal dari kata practiqu/ pratique (Prancis), practicus (Latin), atau praktikos (Yunani) yang secara harfiah berarti "aktif" atau prattein / prassein (Yunani) yang berarti “ mengerjakan”. Dalam bahasa Inggris, praktikum bermakna sama dengan excersice (exercice) [Prancis], exercitium / execere [Latin] yang secara harfiah berarti "tetap aktif/sibuk" yang juga bermakna sama dengan "latihan" atau "responsi". Dalam pelaksanaanya praktikum IPA digunakan oleh guru untuk memperdalam materi maupun menjadi bahan evaluasi sebagai penilaian dari beberapa guru. Materi IPA pada tingkat Sekolah Dasar (SD) lebih sederhana dibandingkan jenjang Sekolah Menengah Pertama (SMP). Beberapa materi diselingi dengan Praktikum IPA yang disajikan dalam bentuk LKS (LKS eksperimen maupun LKS non eksperimen). Pada beberapa materi IPA ditemukan kesamaan jenis atau kemiripan praktikum walaupun evaluasi dalam bentuk pertanyaan berbeda pada setiap jenjang (SD dan SMP). Materi tersebut dapat dilihat pada tabel dibawah ini:

\begin{tabular}{|c|c|c|c|c|}
\hline $\mathrm{NO}$ & Tema Praktikum & SD & SMP & Keterangan/sumber buku \\
\hline I & Listrik dan Magnet & $\mathrm{V}$ & $\mathrm{V}$ & $\begin{array}{l}\text { SD : Priyono. 20I0. Ilmu Pengetahuan Alam } \\
\text { untuk SD dan MI kelas V. Jakarta: Pusat } \\
\text { Perbukuan, kementrian Pendidikan Nasional } \\
\text { SD : Pitoyo, Ari, dan Sr Purwaningtyas. } \\
\text { 20I0. Ilmu Pengetahuan Alam untuk SD/MI } \\
\text { Kelas VI. Jakarta: Pusat Perbukuan, kementrian } \\
\text { Pendidikan Nasional } \\
\quad \text { SMP : Kuswanti, Nur, dkk. 2008. Ilmu } \\
\text { Pengetahuan Alam Sekolah Menengah } \\
\text { Pertama/Madrasah Tsanawiyah Kelas IX Edisi } 4 . \\
\text { Jakarta: Pusat Perbukuan, Departemen Pendidikan } \\
\text { Nasional } \\
\quad \text { SMP : Puspita, Diana, Lip Rohima. 2009. } \\
\text { Alam Sekitar, IPA Terpadu untuk SMP/MTs } \\
\text { kelas IX. Jakarta: Pusat Perbukuan, Departemen } \\
\text { Pendidikan Nasional }\end{array}$ \\
\hline 2 & $\begin{array}{l}\text { Perubahan Wujud } \\
\text { Benda }\end{array}$ & $\mathrm{V}$ & $\mathrm{V}$ & $\begin{array}{l}\text { SD: Amin, Choirul. 2009. Ilmu Pengetahuan } \\
\text { Alam Jilid } 3 \text { untuk SD \& MI kelas 3. Jakarta : } \\
\text { Pusat Perbukuan, Departemen Pendidikan } \\
\text { Nasional } \\
\text { V SMP : Winarsih, Anni, dan Agung } \\
\text { Nugroho. 2008. IPA Terpadu untuk SMP/MTS } \\
\text { kelas VII. Jakarta : Pusat Perbukuan, Departemen } \\
\text { Pendidikan Nasional }\end{array}$ \\
\hline 3 & $\begin{array}{ll}\text { Perubahan } & \text { Pada } \\
\text { Makhluk hidup } & \end{array}$ & V & $\mathrm{V}$ & $\begin{array}{l}\text { SD: Amin, Choirul.2009. Ilmu Pengetahuan } \\
\text { Alam Jilid } 3 \text { untuk SD/Mi Kelas 3. Jakarta: Pusat } \\
\text { Perbukuan, Departemen Pendidikan Nasional } \\
\text { Zien, Ahmad Zulfikar. 2009. Ilmu } \\
\text { Pengetahuan Alam Jilid 3. Jakarta: Pusat } \\
\text { Perbukuan, Departemen Pendidikan Nasional }\end{array}$ \\
\hline 4 & $\begin{array}{l}\text { Sistem gerak pada } \\
\text { tumbuhan }\end{array}$ & $\mathrm{V}$ & V & $\begin{array}{l}\text { SD: Amin, Choirul.2009. Ilmu Pengetahuan } \\
\text { Alam Jilid } 3 \text { untuk SD/Mi Kelas 3. Jakarta: Pusat } \\
\text { Perbukuan, Departemen Pendidikan Nasional }\end{array}$ \\
\hline
\end{tabular}




\begin{tabular}{|c|c|c|c|c|}
\hline & & & & $\begin{array}{l}\text { SMP: Zubaidah, Siti. } 2017 . \\
\text { Pengetahuan Almu } \\
\text { Semester I. Jakarta: Pusat Perbukuan, Departemen } \\
\text { Pendidikan Nasional }\end{array}$ \\
\hline 5 & $\begin{array}{l}\text { Struktur bagian } \\
\text { bunga (perbedaan dan } \\
\text { persamaan pada } \\
\text { tumbuhan monokotil } \\
\text { dan dikotil) }\end{array}$ & $\mathrm{V}$ & $\mathrm{V}$ & $\begin{array}{l}\text { SD: Susilowati, Endang, dan Wiyanto. } 2010 . \\
\text { Ilmu Pengetahuan Alam untuk SD/MI kelas IV. } \\
\text { Jakarta: Pusat Perbukuan, Departemen Pendidikan } \\
\text { Nasional } \\
\text { SMP: Nurachmandani, setya, dan Samson } \\
\text { untuk SMP kelas VIII. Jakarta: Pusat Perbukuan, } \\
\text { Departemen Pendidikan Nasional }\end{array}$ \\
\hline 6 & $\begin{array}{l}\text { Konduktor dan } \\
\text { isolator }\end{array}$ & $\mathrm{V}$ & $\mathrm{V}$ & $\begin{array}{l}\text { SD : Suhartanti, Dwi, dkk. 2008. Ilmu } \\
\text { Pengetahuan Alam kelas } 6 \text { SD. Jakarta : Pusat } \\
\text { Perbukuan, Departemen Pendidikan Nasional } \\
\text { SMP: Karim, Saeful. 2009. Belajar IPA SMP } \\
\text { Kelas VII. Jakarta: Pusat Perbukuan, Departemen } \\
\text { Pendidikan Nasional }\end{array}$ \\
\hline
\end{tabular}

Berdasarkan kajian literature pada tabel I, peneliti menggunakan I2 buku IPA yang kemudian diindentifikasi pada masing-masing jenjang (SD dan SMP) kesamaan jenis praktikum. Walaupun terdapat persamaan pada jenis praktikum pada materi IPA tersebut, salah satu contohnya praktikum membuat rangkaian seri dan parallel, untuk evaluasi soal pada jenjang SMP lebih melatih kemampuan berpikir siswa., sedangkan pada jenjang SD masih sederhana. Guru dapat mensiasati kesamaan jenis praktikum agar tidak terkesan membosankan bagi siswa misalnya saat SD praktikum kecambah menggunakan biji kacang hijau, dan pada jenjang SMP menggunakan biji kacang merah atau biji jagung.

\section{Simpulan}

Berdasarkan hasil kajian literature pada I2 buku peneliti menemukan 6 (enam) kesamaan praktikum pada tingkat SD dan SMP; I) Listrik dan Magnet, 2) Perubahan Wujud Benda, 3) Perubahan Pada Makhluk hidup, 4) Sistem gerak pada tumbuhan, 5) Struktur bagian bunga, dan 6) Konduktor dan isolator.

Peneliti memberikan saran praktikum IPA yang disajikan nantinya, diharapkan guru dapat mengembangkan praktikum terutama untuk meningkatkan dan melatih kemampuan berpikir siswa pada materi IPA terutama keterampilan proses sains. Untuk menghindari kejenuhan jenis praktikum pada beberapa materi harus dibedakan contoh alat atau bahan praktikum yang akan dipraktekkan pada tingkat SD dan SMP apabila materinya sama, karena setiap jenjang memiliki tujuan pencapaian yang berbeda. Apabila jenis praktikum tetap sama bisa disiasati dengan mengembangkan jenis praktikum IPA yang interktif pada salah satu jenjangnya, dan tidak keluar dari konteks materi karena setiap jenjang memiliki tingkatan berpikir yang berbeda.

\section{Referensi}

Ahafni, Sarmila. 20I3. Penilaian Praktikum. http://sarmilahafni.blogspot.com/2013/02/ penilaian-Praktikum.html di akses $30 \mathrm{Mei}$ 2018

Rustaman, N.Y. 1995. Peranan Praktikum dalam Pembelajaran Biologi. Bahan Pelatihan bagi Teknisi dan Laboran Perguruan Tinggi.Kerjasama FPMIPA IKIP Bandung dengan Direktorat Jenderal Pendidikan Tinggi. Bandung: FPMIPA IKIP.

Subiantoro, Agung. 2007. Makalah yang disampaikan pada Kegiatan PPM "Pelatihan Pengembangan Praktikum IPA Berbasis Lingkungan” bagi guru-guru MGMP IPA SMP Kota Yogyakarta. 